\title{
PEMANFAATAN VIDEO KEHAMILAN BERKUALITAS UNTUK MENINGKATKAN PENGETAHUAN IBU HAMIL DI MASA PANDEMIC COVID 19
}

DOI: https://doi.org/10.33024/jkpm.v4i5.4192

Irfan $^{1}$, Ririn Widyastuti ${ }^{*}$, Fitri Handayani ${ }^{3}$

${ }^{1}$ Program Studi Keperawatan, Poltekkes Kemenkes Kupang

${ }^{2 *}$ Program Studi Kebidanan, Poltekkes Kemenkes Kupang

${ }^{3}$ Direktorat Poltekkes Kemenkes Kupang

Disubmit: 11 April 2021 Diterima: 08 Mei $2021 \quad$ Diterbitkan: 30 September 2021

Email korespondensi: ririenwidyastuti@gmail.com

\begin{abstract}
ABSTRAK
Ibu hamil lebih rentan terhadap morbiditas Covid 19 dikarenakan perubahan fisiologis dan imunologis selama masa kehamilan. Salah satu upaya asuhan pada masa pandemi covid untuk mencegah penularan dan penyebaran covid 19 adalah adalah dengan meningkatkan pengetahuan ibu hamil melalui promosi kesehatan tentang kehamilan berkualitas. Tujuan pengabdian masyarakat adalah untuk meningkatkan pengetahun ibu hamil melalui pemberian video kehamilan berkualitas pada masa pandemic covid 19. Pelaksanaan kegiatan pengabdian masyarakat dengan cara memberikan penyuluhan, konseling informasi dan edukasi (KIE) kepada ibu hamil dengan menggunakan media video kehamilan berkualitas di Puskesmas Oepoi Kota Kupang. Analisis univariate disajikan dalam bentuk tabel distribusi frekuensi. Analisis bivariate dengan menggunakan uji paired sample $\mathrm{t}$ - test untuk mengetahui perbedaan sebelum dan setelah pemberian penyuluhan dan KIE pada ibu hamil. Hasil Pengabdian masyarakat adalah terjadi Peningkatan rerata pengetahuan ibu hamil sebelum perlakuan 64.25 dan setelah perlakuan meningkat menjadi 81.08. Hasil uji paired samples t-test menunjukkan bahwa ada perbedaan bermakna pengetahuan ibu hamil tentang kehamilan berkualitas pada masa covid 19 ( $p<0,05)$; Saran: perlu pengembangan telemedicine untuk memberikan asuhan pada masa kehamilan di masa pandemic covid 19.
\end{abstract}

Kata kunci: Ibu hamil, Pengetahuan, Kehamilan berkualitas, Covid 19

\begin{abstract}
ABSTRACK
Pregnant women are more prone to Covid 19 morbidity due to physiological and immunological changes during pregnancy. One of the care efforts during the Covid pandemic to prevent the transmission and spread of Covid 19 is to increase the knowledge of pregnant women through health promotion about quality pregnancies. The aim of community service is to increase the knowledge of pregnant women by providing quality pregnancy videos during the COVID-19 pandemic. Implementation of community service activities by giving counseling, information counseling and education (IEC) to pregnant women using quality pregnancy video media at Oepoi Health Center, Kupang City. Univariate analysis
\end{abstract}


is presented in the form of a frequency distribution table. Bivariate analysis using paired sample t-test to determine the differences before and after counseling and IEC for pregnant women. The result of community service was that there was an increase in the mean knowledge of pregnant women before treatment 64.25 and after treatment increased to 81.08. The results of the paired samples t-test showed that there were significant differences in the knowledge of pregnant women about quality pregnancies during the Covid 19 period ( $p$ <.05); Suggestion: it is necessary to develop telemedicine to provide care during pregnancy during the Covid pandemic 19.

Keywords: Pregnant women, knowledge, quality pregnancy, Covid 19

\section{PENDAHULUAN}

Coronavirus merupakan virus RNA strain tunggal positif, berkapsul dan tidak bersegmen. World Health Organization (WHO) memberi nama virus baru tersebut severe acute respirtorysyndrome coronavirus-2 (SARS-CoV-2) dengan nama penyakitnya adalah Coronavirus Disease 2019 (Covid 19) (WHO, 2020). Covid 19 merupakan infeksi saluran pernafasan yang pertama kali diidentifikasi di Cina. Penularan corona virus melalui tetesan pernafasan dan kontak langsung (Rasmussen, Smulian, Lednicky, Wen, \& Jamieson, 2020). Berdasarkan data WHO (2020), terdapat penambahan kasus di Indonesia sejak tanggal 3 Januari s/d 31 Oktober 2020 adalah 406.945 terkonfirmasi positif covid 19 dengan 13.782 kasus meninggal. Pada kelompok ibu hamil, terdapat $4.9 \%$ ibu hamil terkonfirmasi positif Covid 19 dari 1.483 kasus terkonfirmasi yang memiliki data kondisi penyerta. Data ini menunjukkan bahwa ibu hamil, bersalin, nifas dan bayi baru lahir juga merupakan sasaran yang rentan terhadap infeksi Covid 19 dan kondisi ini dikhawatirkan akan meningkatkan morbiditas dan mortalitas ibu dan bayi baru lahir (Kementrian Kesehatan RI, 2020).

Ibu hamil, kemungkinan lebih rentan terhadap morbiditas Covid 19 dikarenakan perubahan fisiologis dan imunologis selama masa kehamilan. Laporan kasus dan kohort pada ibu dengan Covid 19 menunjukkan gejala ringan seperti demam dan batuk. Hubungan antara Covid 19 dengan kehamilan dapat menyebabkan persalinan prematur, ketuban pecah dini (KPD), Detak Jantung Janin (DJJ) yang tidak normal (Stephens, Barton, Bentum, Blackwell, \& Sibai, 2020). Zeng, Xia, \& Yuan (2020), melaporkan bahwa tiga neonatus dari 33 kohort pasien yang mungkin telah terinfeksi sindrom pernafasan akut coronavirus-2 (SARS-CoV-2) dalam rahim dari ibu dengan Covid 19. Bukti penularan didasarkan pada peningkatan nilai antibodi imunoglobulin (Ig) $M$ dalam darah yang diambil dari neonatus setelah lahir. Tidak ada spesimen bayi yang memiliki hasil tes positif PCR, oleh karena itu, tidak ada bukti virologi untuk infeksi kongenital dalam kasus dari penularan dalam rahim. Studi kedua terhadap enam ibu yang diketahui positif Covid 19 dan bayinya menunjukkan hasil yang serupa. Namun, beberapa penelitian lain belum menunjukkan bukti penularan Covid 19 secara vertical dari ibu ke janinnya.

Salah satu upaya asuhan pada masa pandemi covid untuk mencegah penularan dan penyebaran covid 19 adalah adalah dengan meningkatkan pengetahuan ibu hamil melalui promosi kesehatan tentang kehamilan berkualitas sehingga mereka mau, sadar, dan mampu mempersiapkan dan menikmati proses kehamilan dengan aman dan nyaman serta mencegah 
masalah kesehatannya di masa pandemi. Komunikasi kesehatan mencakup pemanfaatan jasa komunikasi untuk menyampaikan pesan dan mempengaruhi proses pengambilan keputusan yang berhubungan dengan upaya peningkatan dan pengelolaan kesehatan oleh individu maupun masyarakat. Selain itu, komunikasi kesehatan juga meliputi kegiatan menyebarluaskan informasi tentang kesehatan kepada masyarakat agar tercapai perilaku hidup sehat, menciptakan kesadaran, mengubah sikap dan memberikan motivasi pada individu untuk mengadopsi perilaku sehat yang direkomendasikan menjadi tujuan utama komunikasi kesehatan (Rahmadiana, 2012). Kebutuhan akan informasi yang akurat, tepat, dan terkini semakin dibutuhkan seiring dengan perkembangan teknologi informasi yang sangat pesat. Hal ini mendorong masyarakat dan instansi untuk memanfaatkan teknologi informasi. Saat ini, website tidak hanya diakses dengan menggunakan browser di desktop, namun juga di akses di tablet ataupun smartphone (Leonita \& Jalinus, 2018).

\section{MASALAH}

Alasan kami memilih Puskesmas Oepoi adalah Puskesmas Oepoi berada di wilayah kota Kupang sehingga akses media informasi lebih mudah serta jarak lokasi peneliti dengan mitra adalah $4.4 \mathrm{~km}$ dengan waktu tempuh 10 menit. Selain itu kondisi perkembangan covid di NTT yang semakin meningkat sehingga perlu memberikan pemahaman kepada ibu hamil tentang pemeriksaan kehamilan yang perlu didapatkan, sehingga ibu hamil tidak harus pergi ke Puskesmas/fasilitas kesehatan apabila tidak terdapat keluhan.

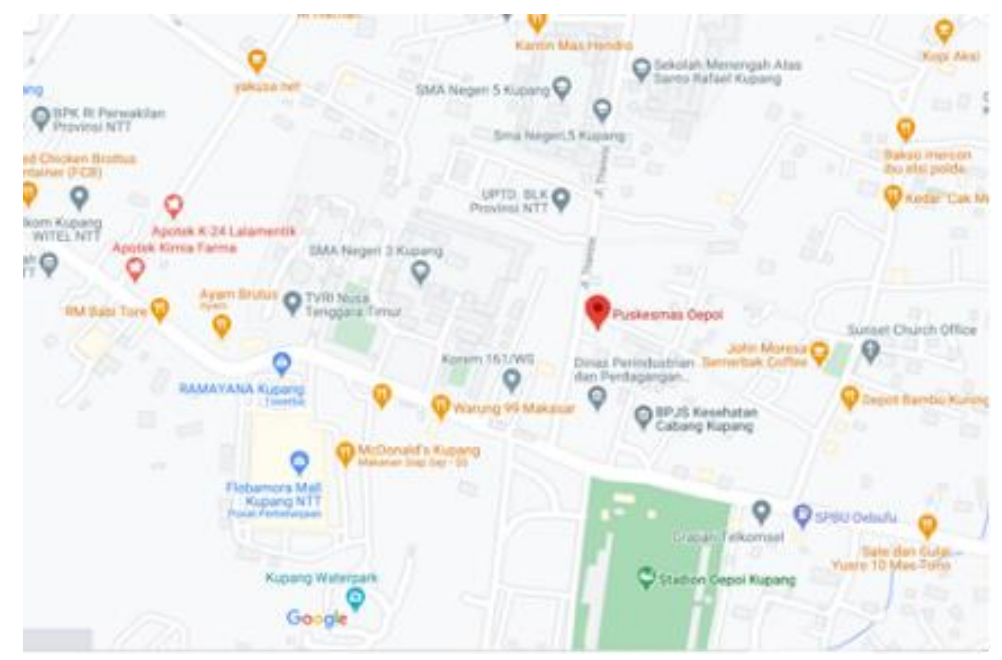

Gambar 2.1 Peta Lokasi Kegiatan Pengbdian Kepada Masyarakat.

\section{METODE}

a. Tujuan Persiapan

Kegiatan yang akan dilakukan pada tahap persiapan adalah persipan lokasi dan tim pelaksana

1) Persiapan dan Pembentukan tim kegiatan pengabdian masyarakat yang terdiri dari dosen dan mahasiswa Poltekkes Kemenkes Kupang serta tim Puskesmas Oepoi dengan pembagian tugas sebagai berikut: 
Tabel 3.1 Persiapan Pengabdian Masyarakat

\begin{tabular}{|l|l|}
\hline \multicolumn{1}{|c|}{ Sasaran } & \multicolumn{1}{|c|}{ Peran } \\
\hline Irfan, SKM., M.Kes & - Mengorganisir dan memfasilitasi \\
Ririn Widyastuti, S.ST., & kegiatan \\
M.Keb & - Penyuluhan dan KIE \\
Fitri Handayani, S.Kep., & - Evaluasi kegiatan \\
MPH & - Koordinasi dengan Tim Poltekkes \\
\hline Bidan Koordinator & $\begin{array}{l}\text { Kemenkes Kupang } \\
\text { Puskesmas Oepoi }\end{array}$ \\
& $\begin{array}{l}\text { Bertanggungjawab atas pelaksanaan } \\
\text { kegiatan pengabdian masyarakat } \\
\text { - Menyiapkan tempat dan sarana } \\
\text { prasana untuk menunjang kegiatan } \\
\text { penyuluhan dan KIE }\end{array}$ \\
\hline Ibu Hamil & \begin{tabular}{l} 
Mendapatkan penyuluhan dan KIE \\
\hline
\end{tabular} \\
\hline
\end{tabular}

2) Menyiapkan alat bahan yang diperlukan untuk pelaksanaan kegiatan pengabdian masyarakat termasuk persiapan format kuisioner pre dan post serta evaluasi kegiatan pengabdian masyarakat.

b. Tahap pelaksanaan

Pelaksanaan kegiatan digambarkan dalam skema dibawah ini:

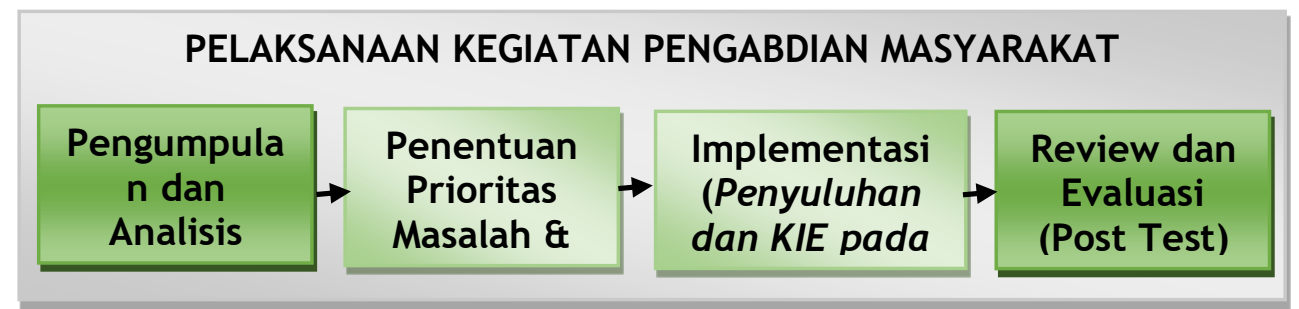

Gambar 3.1 Pelaksanaan Kegiatan Pengabdian Masyarakat

Keterangan

Kegiatan pengabdian kepada masyarakat unuk meningkatkan pengetahuan ibu hamil tentang kehamilan berkualitas dengan uraian sebagai berikut:

a. Pengumpulan dan Analisis Kebutuhan

Pengumpulan dan analisis kebutuhan dengan memberikan 20 pertanyaan pre test tentang kehamilan berkualitas di masa pandemic covid.

b. Penentuan Priorits Masalah dan Solusi Kegiatan

Hasil pre test digunakan untuk menentukan prioritas dan solusi untuk memberikan penyuluhan dan KIE pada ibu hamil.

c. Implementasi

Implementasi kegiatan dalam bentuk penyuluhan dan KIE pada ibu hamil tentang kehamilan berkualitas melalui video pembelajaran di masa pandemic covid

d. Review dan evaluasi pengabdian masyarakat

Review dan evaluasi dengan memberikan post test pada ibu hamil. 
c. Analisa Data

Analisa data dengan menggunakan analisis univariate dan bivariate. Analisis univariate yaitu data yang diperoleh dari hasil pengumpulan data disajikan dalam bentuk tabel distribusi frekuensi. Analisis bivariate dengan menggunakan uji paired sample $t$ - test untuk mengetahui perbedaan sebelum dan setelah pemberian video pembelajaran pada ibu hamil.

\section{HASIL DAN PEMBAHASAN}

\section{a. Hasil Pengabdian Masyarakat}

Tabel 4.1 Distribusi Frekuensi Peningkatan Pengetahuan Ibu Hamil

Tentang Kehamilan Berkualitas Di Masa Pandemi Covid 19

Melalui Pemanfaatan Media Pembelajaran Kehamilan Berkualitas

Di Puskesmas Oepoi Kota Kupang Tahun 2020

\begin{tabular}{|l|r|r|r|r|r|c|}
\hline Pengetahuan & \multicolumn{2}{|c|}{ Pre Test } & \multicolumn{2}{c|}{ Post Test } & Standar & $\begin{array}{c}p- \\
\text { Value }\end{array}$ \\
\cline { 2 - 5 } & \multicolumn{1}{|c|}{$\Sigma$} & $\%$ & $\Sigma$ & $\%$ & Deviasi & Valuen \\
\hline Baik & 6 & 11.7 & 46 & 76.7 & 0.415 & 0,0001 \\
\hline Cukup & 47 & 78.3 & 14 & 23.3 & & \\
\hline Kurang & 7 & 11.7 & 0 & 0,0 & & \\
\hline Total & 60 & 100,0 & 60 & 100,0 & & \\
\hline
\end{tabular}

Tabel 4.2 Rerata Perubahan Pengetahuan Sebelum dan Setelah Pemberian Intervensi Melalui Pemanfaatan Media Pembelajaran Kehamilan Berkualitas Masa Pandemi Covid 19 Di Puskesmas Oepoi Kota Kupang Tahun 2020

\begin{tabular}{|ll|r|r|}
\hline N & Valid & $\begin{array}{c}\text { Sebelum } \\
\text { Intervensi }\end{array}$ & $\begin{array}{c}\text { Setelah } \\
\text { Intervensi }\end{array}$ \\
\cline { 3 - 4 } & Missing & 60 & 60 \\
Mean & & 0 & 0 \\
\hline
\end{tabular}

Berdasarkan grafik 4.1 menunjukkan bahwa terdapat peningkatan pengetahun ibu hamil tentang kehamilan berkualitas pada masa pandemic covid 19. Pengetahuan ibu hamil sebelum diberikan perlakuan adalah baik 6 orang (11.7\%), cukup 47 orang $(78.3 \%)$ dan kurang 7 orang $(11.7 \%)$. Pengetahuan ibu hamil setelah diberikan perlakuan dengan diberikan media pembelajaran kehamilan berkualitas di masa pandemic covid hasilnya adalah 46 ibu hamil (76.7\%) berpengetahuan baik dan 14 ibu hamil (23.3\%) berpengetahuan cukup. Terdapat peningkatan pengetahuan ibu hamil setelah diberikan perlakuan. Pada tabel 4.2 menunjukkan peningkatan rerata pengetahuan ibu hamil yaitu sebelum perlakuan 64.25 dan setelah perlakuan meningkat menjadi 81.08. Hasil uji paired samples $t$-test menunjukkan bahwa ada perbedaan bermakna pengetahuan ibu hamil tentang kehamilan berkualitas pada masa covid $19(\mathrm{p}<0,05)$. Hasil pengabdian masyarakat ini menunjukkan bahwa intervensi pemberian media pembelajaran kehamilan berkualitas pada masa pandemic covid yang diberikan pada ibu hamil efektif untuk meningkatkan pengetahuan ibu hamil. Hal ini dapat dilihat dari peningkatan pengetahuan ibu hamil sebelum dan setelah dilakukan intervensi. 
Hasil ini sejalan dengan hasil penelitian sebelumnya yang menunjukkan bahwa intervensi video kehamilan berkualitas melalui whattapps group yang diberikan selama 2 kali pada ibu hamil efektif untuk meningkatkan pengetahuan ibu hamil. Hal ini dapat dilihat dari peningkatan rerata pengetahuan ibu hamil sebelum dan setelah dilakukan intervensi (Dafroyati \& Widyastuti, 2020). Selain itu, media pembelajaran (video), efektif digunakan sebagai media promosi kesehatan pada masa pandemic covid, meminimalkan ibu hamil untuk pergi ke fasilitas umum termasuk fasilitas kesehatan. Penggunaan video atau media sosial dianggap lebih efektif. Penelitian serupa yang dilakukan sebelumnya oleh Chan \& Chen (2019), melaporkan bahwa penggunaan media sosial dan aplikasi kesehatan dapat meningkatkan kesehatan ibu. Hasil penelitiannya menunjukkan bahwa intervensi menggunakan media sosial dan aplikasi kesehatan dapat meningkatkan kesehatan fisik pada ibu hamil terutaa pada management pengaturan kenaikan berat badan selama hamil pada ibu hamil dengan Diabetus Millitus. Decker, King, \& Lester (2016), dalam penelitiannya melaporkan bahwa 1661 responden mendapatkan informasi tentang kesehatan melalui media sosial. Responden menggunakan media sosial untuk mencari informasi terkait dengan status kesehatan pada ibu hamil. Responden lebih tertarik untuk mendapatkan informasi melalui media online daripada mendiskusikan dengan tenaga kesehatan. Penelitian yang dilakukan oleh Kavlak, Atan, Gulec, Ozturk, \& Atay) 2012), menunjukkan bahwa 45\% ibu hamil menggunakan internet untuk mendapatkan informasi terkait kehamilannya seperti perkembangan janin, nutrisi selama hamil dan informai terkait dengan persalinan. Jayaseelan \& Piichandy, C Rushhandramani (2015), menjelaskan bahwa 100 \% ibu hamil menggunakan smartphone dan aplikasi kesehatan untuk mendapatkan informasi terkait dnegan kehamilannya.

Berikut ini adalah gambar pelaksaan pengabdian masyarakat dengan pemanfaatan video kehamilan berkualitas untuk meningkatkan pengetahuan ibu hamil di masa pandemic covid 19
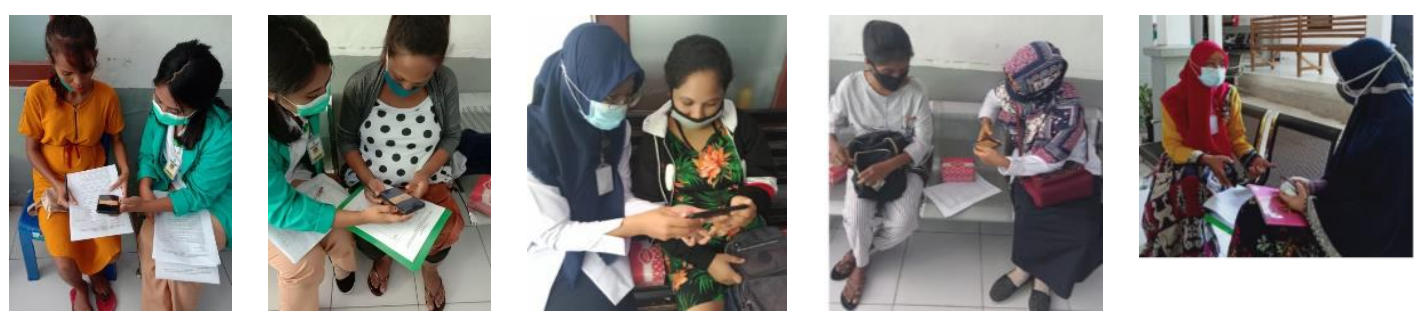

Gambar 4.1 Pemanfaatan Video Kehamilan Berkualitas

\section{KESIMPULAN}

a. Terdapat peningkatan rerata pengetahuan ibu hamil sebelum dan setelah perlakuan/intervensi.

b. Intervensi pemberian media pembelajaran kehamilan berkualitas pada masa pandemic covid yang diberikan pada ibu hamil efektif untuk meningkatkan pengetahuan ibu hamil. 


\section{DAFTAR PUSTAKA}

Chan, K. ., \& Chen, M. (2019). Effects of social media and mobile health apps on pregnancy care: meta analysis. JMIR MHealth Uhealth, 7(1), 1-13.

Dafroyati, Y., \& Widyastuti, R. (2020). The Effectiveness of Health Education about Healthy Pregnancy through WhatsApp Group towards the Knowledge of Pregnant Women at Bakunase Health Center Kupang City 2019. Aloha International Journal of Health Advancement, 3(7), 152-155. Retrieved from

http://journal.aloha.academy/index.php/aijha/article/view/aijha30703/ 30703

Decker, R. ., King, S., \& Lester, K. (2016). Social media and evidence based maternity care: A Cross sectional survey study. The Journal of Perinatal Education, 25(2), 105-115.

Jayaseelan, R., \& Piichandy, C Rushhandramani, D. (2015). Usage of smartphone apps by women on their maternal life. Research J. Science Amd Tech, 7(3), 158-164.

Kavlak, O., Atan, S. ., Gulec, D., Ozturk, D., \& Atay, N. (2012). Pregnant women's use of the internet in relation to their pregnancy in Izmir, Turkey. Informatic for Health and Social Care., 37(4).

Kementrian Kesehatan RI. (2020). Begini Aturan Persalinan di Masa Pandemi COVID-19. Kemenkes RI, (021), 52921669. Retrieved from https://www.kemkes.go.id/article/view/20072000001/begini-aturanpersalinan-di-masa-pandemi-covid-19.html

Leonita, E., \& Jalinus, N. (2018). The Role of Social Media in Health Promotion Efforts: A Literature Review (Peran Media Sosial Dalam Upaya Promosi Kesehatan: Tinjauan Literatur). Invotek: Jurnal Inovasi Vokasional Dan Teknologi, 18(2), 25-34. https://doi.org/10.24036/invotek.v18i2.261

Rahmadiana, M. (2012). Health Communication (Komunikasi Kesehatan). Jurnal Psikogenesis, 1(1).

Rasmussen, S., Smulian, J., Lednicky, J., Wen, T., \& Jamieson, D. (2020). Coronavirus Disease 2019 (COVID-19) and pregnancy: what obstetricians need to know. Am J Obstet Gynecol. https: / /doi.org/10.1016/j.ajog.2020.02.017

Stephens, A. J., Barton, J. R., Bentum, N. A. A., Blackwell, S. C., \& Sibai, B. M. (2020). General Guidelines in the Management of an Obstetrical Patient on the Labor and Delivery Unit during the COVID-19 Pandemic. American Journal of Perinatology, 37(8), 829-836. https://doi.org/10.1055/s-00401710308

WHO. (2020). Coronavirus Disease 2019 (Covid-19) Situation Report.

Zeng, L., Xia, S., \& Yuan, W. (2020). born to mothers with COVID-19 in Wuhan, China. JAMA Pediatr. https://doi.org/10.1001/jamapediatrics.2020.0878 